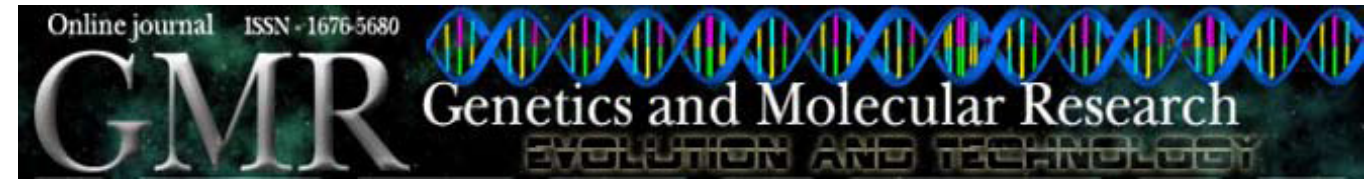

\title{
Lack of association of single nucleotide polymorphisms of the bovine Flt-1 gene with growth traits in Chinese cattle breeds
}

\author{
Y.H. Pang ${ }^{1,2}$, C.Z. Lei ${ }^{1}$, C.L. Zhang ${ }^{2}$, X.Y. Lan ${ }^{1}$, S. Shao ${ }^{2}$, X.M. Gao ${ }^{2}$, \\ J.Q. Wang ${ }^{3}$ and H. Chen ${ }^{1}$ \\ ${ }^{1}$ College of Animal Science and Technology, Northwest A and F University, \\ Shaanxi Key Laboratory of Molecular Biology for Agriculture, Yangling, \\ Shaanxi, China \\ ${ }^{2}$ Institute of Cellular and Molecular Biology, Xuzhou Normal University, \\ Xuzhou, Jiangsu, China \\ ${ }^{3}$ Research Center of Cattle Engineering Technology in Henan, Zhengzhou, \\ Henan, PR China
}

Genet. Mol. Res. 10 (1): 359-367 (2011)

Received August 27, 2010

Accepted December 8, 2010

Published March 1, 2011

DOI 10.4238/vol10-1gmr1041

Corresponding author: H. Chen

E-mail: chenhong1212@263.net

\begin{abstract}
We analyzed 20 exons, with their intron-exon boundaries, of the bovine Flt-1 gene, using a strategy combining PCR amplification and single-strand conformational polymorphism analysis (PCR-SSCP), followed by nucleotide sequence analysis, in 675 cattle. We then looked for associations between polymorphisms and growth traits. Twelve novel SNPs (ss\#184956516, ss\#184956517, ss\#184956518, ss\#184956519, ss\#251343993, ss\#251343994, ss\#251343995, ss\#251343996, ss\#251343997, ss\#251343998, ss\#251343999, and ss\#251344000) were detected in the bovine Flt-1 gene in all three breeds. We observed no significant associations between these polymorphisms and birth weight, body weight and average daily gain during different growth periods (6, 12,18 , and 24 months old) $(\mathrm{P}>0.05)$, or in body height, body length, heart girth, or height at the hip in Nanyang cattle breeds.
\end{abstract}

Key words: Single nucleotide polymorphism; Chinese cattle; Flt-1 gene 


\section{INTRODUCTION}

Increased knowledge of the molecular basis has indicated that mutations in some genes play a major role in animal development and growth. Altered forms of some of these genes have already been shown to be potential prognostic markers in growth traits. Thus, in addition to basic research, analysis of genetic polymorphism has also become more important for animal molecular breeding.

Flt-1 (fms-like tyrosine kinase) is a transmembrane receptor in the tyrosine kinase family for vascular endothelial growth factor (VEGF) (De Vries et al., 1992). The VEGF gene family consists of seven members, VEGF-A, VEGF-B, VEGF-C, VEGF-D, VEGF-E, VEGF-F, and placental growth factor (Ferrara et al., 2003; Alitalo et al., 2005). Research conducted for almost two decades has established that VEGF (also referred as VEGF-A) is a key positive mediator of developmental angiogenesis associated with various physiological conditions including skeletal muscle capillarity (Tang et al., 2004), bone formation during normal bone development (Peng et al., 2005), and regulation of obesity (Cao et al., 2008). In previous studies, we reported that the polymorphisms of the $V E G F$ gene had a positive effect on bovine growth traits and that the single nucleotide polymorphism (SNP; ss130456744) in intron 2 may be a molecular breeding marker in breeding strategies through MAS (marker-assisted selection) in Chinese domestic cattle (Pang et al., 2010). VEGF binds two highly related receptor tyrosine kinases (RTK), Flt-1 (VEGFR1) and KDR/Flk-1 (VEGFR2). Flt-1 was the first RTK to be identified as a VEGF receptor (De Vries et al., 1992). Increased Flt-1 expression was reported in endothelial cells during development (Quinn et al., 1993). Combined with Flt-1 gene knock-out and receptor-blocking studies, these data suggest that the Flt-1 signaling system may have important regulatory roles during postnatal development (Autiero et al., 2003). However, the variations in the Flt-1 gene have not been investigated. The aim of this study was to evaluate variation in the Flt-1 gene and to test the association of these polymorphisms with body growth in 675 samples in three Chinese cattle breeds. We also try to understand whether these polymorphisms are genetic markers in cattle breeding traits and whether they can be used in breeding strategies through MAS.

\section{MATERIAL AND METHODS}

\section{DNA samples}

Blood samples were obtained from 675 individuals belonging to three native Chinese cattle breeds (without genetic relationships): Nanyang $(\mathrm{N}=275)$, Jiaxian $(\mathrm{N}=143)$, Qinchuan ( $\mathrm{N}$ $=257$ ). Many records of growth traits and body size traits (body height, body length, chest girth, hucklebone width, body weight, and average daily gain) for different growth periods $(6,12,18$, and 24 months) in the Nanyang breed were collected for statistical analysis. Genomic DNA was extracted from blood samples according to standard procedures (Sambrook and Russell, 2001).

\section{PCR amplification}

The bovine Flt- 1 gene is organized into 31 exons, separated by 30 introns, and its coding region spans approximately $14 \mathrm{~kb}$. It has been assigned to chromosome 12 (http://www. ncbi.nlm.nih.gov). 


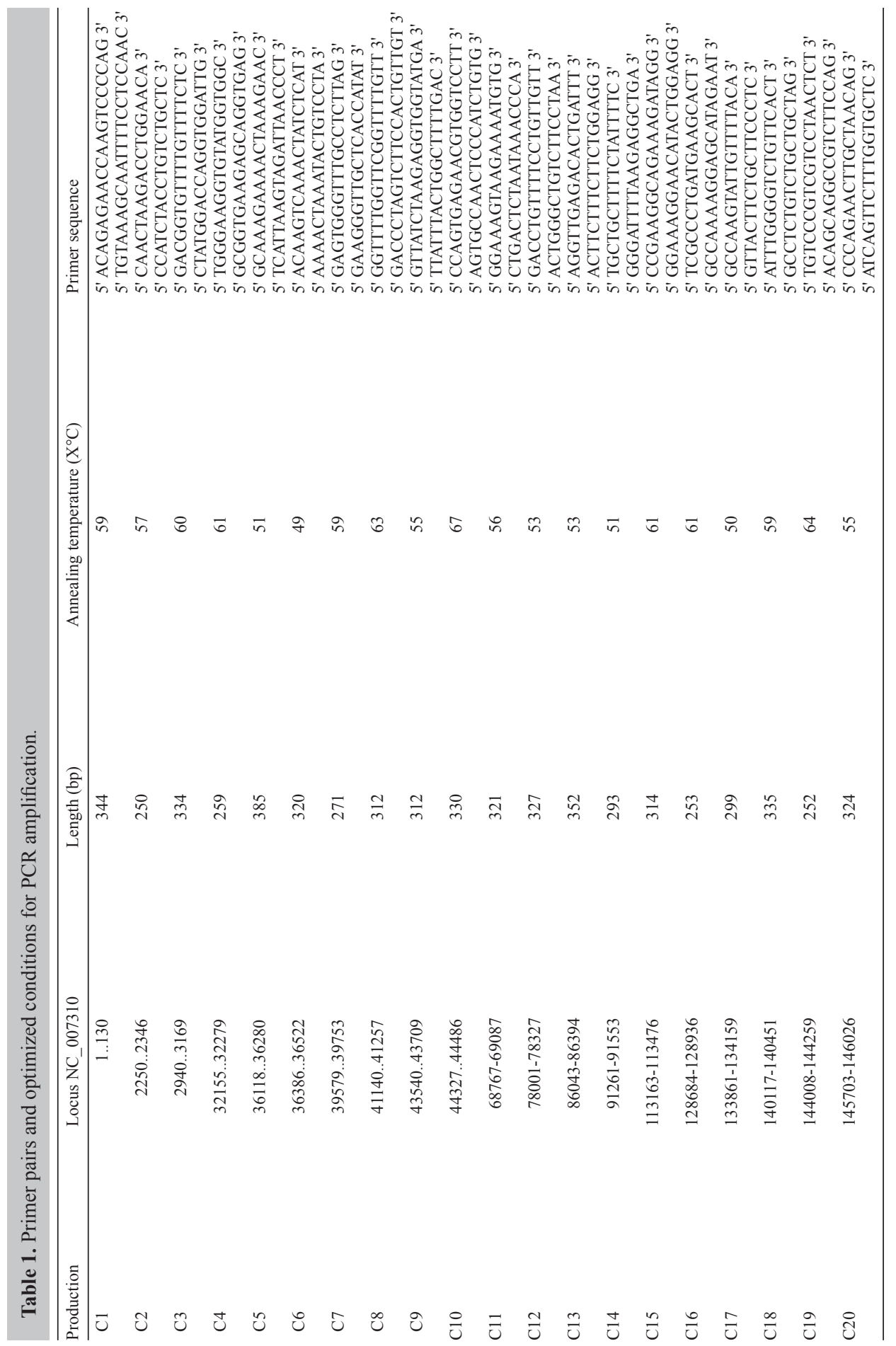


Polymerase chain reaction (PCR) was used to amplify the Flt-1 gene fragments from bovine genomic DNA. The exon-specific oligonucleotide primers were designed according to the nucleotide sequence of the bovine Flt-1 gene reported by GenBank NC_007310. The location and sequences of the primers and the length of the amplified DNA fragments are shown in Table 1. PCR amplification was carried out in a T-gradient thermal cycler (Biometra, Germany) in a volume of $25 \mu \mathrm{L}$, using $0.5 \mathrm{U}$ Taq DNA polymerase, 1X PCR buffer with 2.5 $\mathrm{mM} \mathrm{MgCl}{ }_{2}, 10$ pmol of each primer, each dNTP at $200 \mu \mathrm{M}$ (all TaKaRa, Dalian, China) and 50 ng DNA template.

PCR was performed under the following conditions: $94^{\circ} \mathrm{C}$ for 5 min followed by 35 cycles of $94^{\circ} \mathrm{C}$ for $40 \mathrm{~s}$, annealing at $\mathrm{X}^{\circ} \mathrm{C}$ (see Table 1) corresponding to 10 different primer pairs for $30 \mathrm{~s}$, and $72^{\circ} \mathrm{C}$ for $1 \mathrm{~min}$, and a final extension at $72^{\circ} \mathrm{C}$ for $10 \mathrm{~min}$.

\section{SSCP analysis}

For single-strand conformational polymorphism (SSCP) analysis, the PCR products were mixed with an equal volume $(5 \mu \mathrm{L})$ of formamide loading dye ( $98 \%$ deionized formamide, $0.05 \%$ bromophenol blue and $0.05 \%$ xylene cyanol). The mixture was heated at $98^{\circ} \mathrm{C}$ for 10 min to denature the DNA. After denaturation, the sample was chilled on ice for $10 \mathrm{~min}$, and immediately followed by loading on a gel. Electrophoresis was carried out at $50 \mathrm{~mA}$ and $130 \mathrm{~V}$ for $17 \mathrm{~h}$ at $4^{\circ} \mathrm{C}$. DNA fragments were visualized by silver staining method (Tebbe et al., 2001).

\section{Nucleotide sequence analysis}

SSCP method was used to scan mutations within the amplified regions. Confirmation of the presence of mutation was done by DNA sequencing. The PCR fragments from different SSCP patterns in different breeds were cleaned up and sequenced in both directions in an ABI PRISM 3730 DNA analyzer (Applied Biosystems, USA).

\section{Statistical analysis}

The linear model was applied to analyze the association of the variations in the Flt-1 gene with growth traits in the Nanyang breed. The following model for the PCR-SSCP marker effect was used for analysis: $\mathrm{Y}=1+$ age + marker $+\mathrm{e}$, where $Y$ is the phenotype of the animal, $l$ is the mean of the population, age is the age effect, marker is the marked haplotype effect, and $e$ is the stochastic error. Descriptive data for continuous variables were reported as means \pm SD unless otherwise stated. Two-sided $\mathrm{P}$ values below 0.05 were considered to be statistically significant. Data were analyzed with the SPSS software (version 16.0).

\section{RESULTS}

\section{SNP of Flt-1 gene in three Chinese cattle breeds}

The SSCP analysis indicated that there was no polymorphism in the $\mathrm{C} 1, \mathrm{C} 3, \mathrm{C} 5, \mathrm{C} 6$, $\mathrm{C} 7, \mathrm{C} 8, \mathrm{C} 15, \mathrm{C} 18$, and $\mathrm{C} 19$ loci of Flt-1 gene and that mutations occurred in the $\mathrm{C} 2, \mathrm{C} 4, \mathrm{C} 9$, $\mathrm{C} 10, \mathrm{C} 11, \mathrm{C} 12, \mathrm{C} 13, \mathrm{C} 14, \mathrm{C} 16, \mathrm{C} 17$, and $\mathrm{C} 20$ of the Flt-1 gene, respectively, in the ampli- 
fied regions. Compared with the sequence of the bovine Flt-1 gene (GenBank accession No. NC_007310), 12 novel SNPs (NC_007310: g.2260A $>$ G, 32255C $>$ A, 43654G $>$ C, 44409C $>$ G, $68859 \mathrm{G}>\mathrm{A}, 68872 \mathrm{G}>\mathrm{A}, 78152 \mathrm{C}>\mathrm{G}, 86197 \mathrm{~A}>\mathrm{T}, 91417 \mathrm{G}>\mathrm{C}, 128783 \mathrm{C}>\mathrm{G}, 133972 \mathrm{~A}>\mathrm{G}$, and $145849 \mathrm{C}>\mathrm{T}$ ) were detected in the three breeds. Twelve new SNPs were named FLT1-SNP2260, FLT1-SNP32255, FLT1-SNP43654, FLT1-SNP44409, FLT-SNP68859, FLT-SNP68872, FLT-SNP78152, FLT-SNP86197, FLT-SNP91417, FLT-SNP128783, FLT-SNP133972, and FLT-SNP145849, respectively, and submitted to the GenBank database (ss\#184956516ss\#184956519 and ss\#251343993-ss\#251344000). The SNP locations in the gene, GenBank accession numbers and positions (intron/exon, etc.) are listed in Table 2.

\begin{tabular}{|c|c|c|c|c|}
\hline SNP name & Location NC_007310 & Base position & NCBI_ss\# & SNP \\
\hline FLT1-SNP2260 & Exon2 & 2260 & 184956516 & $\mathrm{~A} / \mathrm{G}$ \\
\hline FLT1-SNP32255 & Exon4 & 32255 & 184956517 & $\mathrm{C} / \mathrm{A}$ \\
\hline FLT1-SNP43654 & Exon9 & 43654 & 184956518 & $\mathrm{G} / \mathrm{C}$ \\
\hline FLT1-SNP44409 & Exon10 & 44409 & 184956519 & $\mathrm{C} / \mathrm{G}$ \\
\hline FLT-SNP 68859 & Intron10 & 68859 & 251343993 & $\mathrm{G} / \mathrm{A}$ \\
\hline FLT-SNP 68872 & Intron10 & 68872 & 251343994 & $\mathrm{G} / \mathrm{A}$ \\
\hline FLT-SNP78152 & Intron11 & 78152 & 251343995 & $\mathrm{C} / \mathrm{G}$ \\
\hline FLT-SNP86197 & Exon13 & 86197 & 251343996 & $\mathrm{~A} / \mathrm{T}$ \\
\hline FLT-SNP91417 & Exon14 & 91417 & 251343997 & $\mathrm{G} / \mathrm{C}$ \\
\hline FLT-SNP128783 & Intron15 & 128783 & 251343998 & $\mathrm{C} / \mathrm{G}$ \\
\hline FLT-SNP133972 & Exon17 & 133972 & 251343999 & $\mathrm{~A} / \mathrm{G}$ \\
\hline FLT-SNP145849 & Exon20 & 145849 & 251344000 & $\mathrm{C} / \mathrm{T}$ \\
\hline
\end{tabular}

$\mathrm{NCBI}=$ National Center for Biotechnology Information.

Being located in the intron regions, four SNPs did not cause amino acid (aa) substitution. Eight SNPs were detected in exon regions and may cause eight synonymous mutations (Table 3): TCA (Ser) $>$ TCG (Ser) at position 47th aa, CCC (Pro) $>$ CCA (Pro) at position 186th aa, CTG (Leu) $>$ CTC (Leu) at position 430th aa, ACC (Thr) $>$ ACG (Thr) at position 476th aa, ATA (Ile) $>$ ATT (Ile) at position 610th aa, ACG (Thr) $>$ ACC (Thr) at position 701st aa, TCA (Ser) $>$ TCG (Ser) at position 819th aa, AAC (Asn) > AAT (Asn) at position 942nd aa of FLT-1 (1359 aa, NCBI Reference Sequence: XP_001249769.2) in the three cattle breeds.

\section{Table 3. Eight synonymous mutations in exon regions of Flt-1 gene.}

\begin{tabular}{llll}
\hline NCBI_ss $\#$ & SNP & Synonymous mutation & Amino acid position (1359 aa) NCBI : XP_001249769.2 \\
\hline 184956516 & A/G & TCA (Ser) $>$ TCG (Ser) & 47 \\
184956517 & C/A & CCC (Pro) $>$ CCA (Pro) & 186 \\
184956518 & G/C & CTG (Leu) $>$ CTC (Leu) & 430 \\
184956519 & C/G & ACC (Thr) $>$ ACG (Thr) & 476 \\
251343996 & A/T & ATA (Ile) $>$ ATT (Ile) & 610 \\
251343997 & G/C & ACG (Thr) $>$ ACC $($ Thr) & 701 \\
251343999 & A/G & TCA (Ser) $>$ TCG (Ser) & 819 \\
251344000 & C/T & AAC (Asn) $>$ AAT (Asn) & 942 \\
\hline
\end{tabular}

$\mathrm{NCBI}=$ National Center for Biotechnology Information; SNP = single nucleotide polymorphism. 


\section{Genotype frequencies}

A total of 675 animals were genotyped at all 12 SNPs; however, successful genotype assignment was not possible for all animals, in particular for the SNPs 184956517, 184956518, 251343993, 251343994, 251343995, and 251344000, where animals were missing genotypes in Qinchuan and Jiaxian Red breeds. The genotype frequency of 12 SNPs varied differently (Table 4).

\begin{tabular}{|c|c|c|c|c|c|c|c|c|}
\hline \multirow{3}{*}{$\begin{array}{l}\text { NCBI_ss\# } \\
184956516\end{array}$} & \multirow{3}{*}{$\begin{array}{l}\text { SNP } \\
\mathrm{A} / \mathrm{G}\end{array}$} & \multirow{3}{*}{$\begin{array}{c}\text { Genotype } \\
\text { AA }\end{array}$} & \multicolumn{6}{|c|}{ Genotype frequency } \\
\hline & & & \multicolumn{2}{|c|}{$\mathrm{NY}(\mathrm{N}=275)$} & \multicolumn{2}{|c|}{$\mathrm{JX}(\mathrm{N}=143)$} & \multicolumn{2}{|c|}{$\mathrm{QC}(\mathrm{N}=257)$} \\
\hline & & & 206 & 0.7491 & 103 & 0.7203 & 222 & 0.8638 \\
\hline & & AG & 53 & 0.1927 & 35 & 0.2448 & 32 & 0.1245 \\
\hline & & GG & 16 & 0.0582 & 5 & 0.0350 & 3 & 0.0117 \\
\hline \multirow[t]{3}{*}{184956517} & $\mathrm{C} / \mathrm{A}$ & $\mathrm{CC}$ & 222 & 0.8073 & 128 & 0.8951 & 236 & 0.9183 \\
\hline & & $\mathrm{CA}$ & 53 & 0.1927 & 15 & 0.1049 & 21 & 0.0817 \\
\hline & & $\mathrm{AA}$ & 0 & 0 & 0 & 0 & 0 & 0 \\
\hline \multirow[t]{3}{*}{184956518} & $\mathrm{G} / \mathrm{C}$ & GG & 212 & 0.7709 & 126 & 0.8811 & 247 & 0.9611 \\
\hline & & GC & 63 & 0.2291 & 17 & 0.1189 & 10 & 0.0389 \\
\hline & & $\mathrm{CC}$ & 0 & 0 & 0 & 0 & 0 & 0 \\
\hline \multirow[t]{3}{*}{184956519} & $\mathrm{C} / \mathrm{G}$ & $\mathrm{CC}$ & 121 & 0.4400 & 57 & 0.3986 & 210 & 0.8171 \\
\hline & & $\mathrm{CG}$ & 91 & 0.3309 & 66 & 0.4615 & 37 & 0.1440 \\
\hline & & GG & 63 & 0.2291 & 20 & 0.1399 & 10 & 0.0389 \\
\hline \multirow[t]{3}{*}{251343993} & $\mathrm{G} / \mathrm{A}$ & GG & 241 & 0.8764 & 143 & 1.0000 & 257 & 1.0000 \\
\hline & & $\mathrm{AG}$ & 34 & 0.1236 & 0 & 0 & 0 & 0 \\
\hline & & $\mathrm{AA}$ & 0 & 0 & 0 & 0 & 0 & 0 \\
\hline \multirow[t]{3}{*}{251343994} & $\mathrm{G} / \mathrm{A}$ & GG & 241 & 0.8764 & 143 & 1.0000 & 257 & 1.0000 \\
\hline & & $\mathrm{AG}$ & 34 & 0.1236 & 0 & 0 & 0 & 0 \\
\hline & & $\mathrm{AA}$ & 0 & 0 & 0 & 0 & 0 & 0 \\
\hline \multirow[t]{3}{*}{251343995} & $\mathrm{C} / \mathrm{G}$ & $\mathrm{CC}$ & 252 & 0.9164 & 143 & 1.0000 & 257 & 1.0000 \\
\hline & & $\mathrm{CG}$ & 23 & 0.0836 & 0 & 0 & 0 & 0 \\
\hline & & GG & 0 & 0 & 0 & 0 & 0 & 0 \\
\hline \multirow[t]{3}{*}{251343996} & $\mathrm{~A} / \mathrm{T}$ & AA & 97 & 0.3527 & 55 & 0.3846 & 105 & 0.4086 \\
\hline & & $\mathrm{AT}$ & 104 & 0.3782 & 68 & 0.4755 & 90 & 0.3502 \\
\hline & & TT & 74 & 0.2691 & 20 & 0.1399 & 62 & 0.2412 \\
\hline \multirow[t]{3}{*}{251343997} & $\mathrm{G} / \mathrm{C}$ & GG & 80 & 0.2909 & 40 & 0.2797 & 98 & 0.3813 \\
\hline & & GC & 98 & 0.3564 & 76 & 0.5315 & 147 & 0.5720 \\
\hline & & $\mathrm{CC}$ & 97 & 0.3527 & 27 & 0.1888 & 12 & 0.0467 \\
\hline \multirow[t]{3}{*}{251343998} & $\mathrm{C} / \mathrm{G}$ & $\mathrm{CC}$ & 110 & 0.4000 & 42 & 0.2937 & 27 & 0.1051 \\
\hline & & $\mathrm{CG}$ & 128 & 0.4655 & 45 & 0.3147 & 182 & 0.7082 \\
\hline & & GG & 37 & 0.1345 & 56 & 0.3916 & 48 & 0.1868 \\
\hline \multirow[t]{3}{*}{251343999} & $\mathrm{~A} / \mathrm{G}$ & $\mathrm{AA}$ & 29 & 0.1055 & 3 & 0.0210 & 37 & 0.1440 \\
\hline & & $\mathrm{AG}$ & 154 & 0.5600 & 55 & 0.3846 & 113 & 0.4400 \\
\hline & & GG & 92 & 0.3345 & 85 & 0.5944 & 107 & 0.4163 \\
\hline \multirow[t]{3}{*}{251344000} & $\mathrm{C} / \mathrm{T}$ & $\mathrm{CC}$ & 252 & 0.9164 & 143 & 1.0000 & 257 & 1.0000 \\
\hline & & $\mathrm{CT}$ & 23 & 0.0836 & 0 & 0 & 0 & 0 \\
\hline & & TT & 0 & 0 & 0 & 0 & 0 & 0 \\
\hline
\end{tabular}

NCBI = National Center for Biotechnology Information; SNP = single nucleotide polymorphism.

\section{Lack of association of SNPs of the Flt-1 with growth traits in Nanyang cattle breed}

The relationship between the different genotypes of each SNP and the various traits recorded was evaluated using a single-marker mixed-model association analysis. Genotypes for the 12 SNPs tested did not significantly influence any of the 6 traits measured. The data containing genotype means, standard errors, $\mathrm{P}$ values, estimates of additive and dominance effects for SNP with significant trait associations were not shown. 


\section{DISCUSSION}

Nanyang, Qinchuan and Jiaxian Red breeds have been important cattle breeds in China for thousands of years. People have long been using a conventional breeding method to improve multiple traits of beef cattle, which calls for a long cycle and causes low efficiency. In recent years, with the development and application of molecular biotechnology, MAS can complement the traditional breeding method. MAS has the potential to significantly increase the rate of genetic improvement in some traits (MacNeil and Grosz, 2002), using markers linked to economically relevant traits, which can be used to predict the genetic merit of an animal. Several such markers have been identified in the last decade. These markers included polymorphisms in the LEP (leptin) gene, involved in the control of appetite and energy metabolism, which have been shown to be associated with body weight and body size indexes (Yang et al., 2007). The polymorphisms of the GHRHR gene (growth hormone-releasing hormone receptor) was associated with average daily gain in Chinese bovine breeds (Zhang et al., 2008). Variations detected in the PRKABI (protein kinase, AMP-activated, beta 1 noncatalytic subunit) gene underpin the development of gene markers for bovine energy balance and in glycogen metabolism (Zhang et al., 2009).

There is a considerable complexity in VEGF signaling. VEGF and its two transmembrane tyrosine-kinase receptors, Flt-1 (VEGFR1) and KDR/Flk-1 (VEGFR2), constitute a ligand-receptor signaling system that is crucial for developmental angiogenesis. Flt-1 was the first RTK identified as a VEGF receptor (De Vries et al., 1992), but the precise function of this molecule is still debated in the field (Ferrara, 2004). The functions and signaling properties of Flt-1 appear to vary with the developmental stage and the cell type, e.g., endothelial versus nonendothelial cells. In spite of the uncertain role of Flt-1 as a signaling receptor, knockout studies have demonstrated its essential role during embryogenesis. Flt- $1^{-1-}$ mice die in utero between day 8.5 and 9.5 (Giantonio et al., 2007), because endothelial cells develop but fail to organize in normal vascular channels. Excessive proliferation of angioblasts has been reported to be responsible for such disorganization and lethality (Yang et al., 2003), lending support to the hypothesis that, at least during early development, Flt-1 is a negative regulator of VEGF action.

In a previous study, we reported a significant association between the $V E G F$ gene and cattle growth traits in three Chinese cattle breeds (Pang et al., 2010). In this subsequent study, we aimed to investigate the VEGF receptor (Flt-1) as a candidate gene affecting growth traits in Chinese cattle. Given that Flt-1 is a member of the VEGF signal transduction pathway and that it is expressed in the muscle, bone and fat, it was chosen for the investigation of its association with growth traits. Statistical results, however, showed no significant relationship between the Flt-1 polymorphism system and growth traits in the Nanyang breed in different growth periods. Therefore, we cannot suggest that the C2, C4, C9, C10, C11, C12, C13, C14, $\mathrm{C} 16, \mathrm{C} 17$, and $\mathrm{C} 20$ loci had a positive or negative effect on bovine growth traits, although $\mathrm{C} 2, \mathrm{C} 4, \mathrm{C} 9, \mathrm{C} 10 \mathrm{C} 11, \mathrm{C} 12, \mathrm{C} 13, \mathrm{C} 14, \mathrm{C} 16, \mathrm{C} 17$, and $\mathrm{C} 20$ loci within the bovine Flt-1 gene were not considered as a DNA marker for bovine growth traits in MAS. A larger sample size (including Qinchuan and Jiaxian Red cattle breeds) and other SNPs of bovine Flt-1 gene (from exon 20 to exon 30) are needed to confirm our findings. The novel SNPs identified by using PCR-SSCP and DNA sequencing methods has extended the spectrum of genetic variation in the bovine Flt-1 gene, which may contribute to a better understanding of genetic variation in animal resources. 


\section{CONCLUSIONS}

This study is the first to investigate the association of these polymorphisms of Flt1 gene with body growth in three Chinese cattle breeds. We have reported 12 novel SNPs. These sequence data have been submitted to the GenBank databases under accession Nos. ss\#184956516-ss\#184956519 and ss\#251343993-ss\#251344000. Statistical results showed no significant relationship between the Flt-1 polymorphism system and growth traits in the Nanyang breed in different growth periods. We conclude that the identified SNPs of the Flt-1 gene cannot be considered as a DNA marker for bovine growth traits in MAS. Other SNPs of Flt-1 gene should be further studied.

\section{ACKNOWLEDGMENTS}

Research supported by the National 863 Program of China (\#2008AA101010), National Natural Science Foundation of China (\#30972080), National Key Technology R\&D Program (\#2008BADB2B03-19), Keystone Project of Transfer Gene in China (\#2009ZX08009-157B, \#2008ZX08007-002, 2009ZX08007-005B-07), MaTS-Beef Cattle System (\#Nycytx-38), and Basic and Foreland Technology Study Program of Henan Province (\#072300430160).

\section{REFERENCES}

Alitalo K, Tammela T and Petrova TV (2005). Lymphangiogenesis in development and human disease. Nature 438: $946-$ 953.

Autiero M, Luttun A, Tjwa M and Carmeliet P (2003). Placental growth factor and its receptor, vascular endothelial growth factor receptor-1: novel targets for stimulation of ischemic tissue revascularization and inhibition of angiogenic and inflammatory disorders. J. Thromb. Haemost. 1: 1356-1370.

Cao H, Urban JF Jr and Anderson RA (2008). Insulin increases tristetraprolin and decreases VEGF gene expression in mouse 3T3-L1 adipocytes. Obesity 16: 1208-1218.

De Vries C, Escobedo JA, Ueno H, Houck K, et al. (1992). The fms-like tyrosine kinase, a receptor for vascular endothelial growth factor. Science 255: 989-991.

Ferrara N (2004). Vascular endothelial growth factor: basic science and clinical progress. Endocrinol. Rev. 25: 581-611.

Ferrara N, Gerber HP and LeCouter J (2003). The biology of VEGF and its receptors. Nat. Med. 9: 669-676.

Giantonio BJ, Catalano PJ, Meropol NJ, O’Dwyer PJ, et al. (2007). Bevacizumab in combination with oxaliplatin, fluorouracil, and leucovorin (FOLFOX4) for previously treated metastatic colorectal cancer: results from the Eastern Cooperative Oncology Group Study E3200. J. Clin. Oncol. 25: 1539-1544.

MacNeil MD and Grosz MD (2002). Genome-wide scans for QTL affecting carcass traits in Hereford x composite double backcross populations. J. Anim. Sci. 80: 2316-2324.

Pang Y, Lei C, Zhang C, Lan X, et al. (2010). The polymorphisms of bovine VEGF gene and their associations with growth traits in Chinese cattle. Mol. Biol. Rep. DOI: 10.1007/s11033-010-0163-6.

Peng H, Usas A, Olshanski A, Ho AM, et al. (2005). VEGF improves, whereas sFlt1 inhibits, BMP2-induced bone formation and bone healing through modulation of angiogenesis. J. Bone Miner. Res. 20: 2017-2027.

Quinn TP, Peters KG, de Vries C, Ferrara N, et al. (1993). Fetal liver kinase 1 is a receptor for vascular endothelial growth factor and is selectively expressed in vascular endothelium. Proc. Natl. Acad. Sci. U. S. A. 90: 7533-7537.

Sambrook J and Russell DW (2001). Molecular Cloning: A Laboratory Manual. Cold Spring Harbor Laboratory Press, New York.

Tang K, Breen EC, Gerber HP, Ferrara NM, et al. (2004). Capillary regression in vascular endothelial growth factordeficient skeletal muscle. Physiol. Genomics 18: 63-69.

Tebbe CC, Schmalenberger A, Peters S and Schwieger F (2001). Single Strand Conformation Polymorphism (SSCP) for Microbial Community Analysis. In: Environmental Molecular Microbiology: Protocols and Applications (Rochelle PA, ed.). Horizon Scientific Press, Wymondham, 161-175.

Yang D, Chen H, Wang X, Tian Z, et al. (2007). Association of polymorphisms of leptin gene with body weight and body 
sizes indexes in Chinese indigenous cattle. J. Genet. Genomics 34: 400-405.

Yang JC, Haworth L, Sherry RM, Hwu P, et al. (2003). A randomized trial of bevacizumab, an anti-vascular endothelial growth factor antibody, for metastatic renal cancer. N. Engl. J. Med. 349: 427-434.

Zhang C, Chen H, Zhang L, Zhao M, et al. (2008). Association of polymorphisms of the GHRHR gene with growth traits in cattle. Arch. Tierz. 51: 300-301.

Zhang Q, Chen H, Zhao S, Zhang L, et al. (2009). Single nucleotide polymorphisms and haplotypic diversity in the bovine PRKAB1 gene. Mol. Biotechnol. 43: 193-199. 